\title{
The Ability of Students Develop Narrative Paragraphs by Using Flash Card
}

Jelita Lumban Gaol

STKIP Pelita Bangsa, Binjai, Sumatera Utara, Indonesia

\begin{tabular}{|c|c|}
\hline ART ICLE I NFO & ABSTRACT \\
\hline $\begin{array}{r}\text { Keywords: } \\
\text { Narrative Paragraphs; } \\
\text { Flash Card; } \\
\text { Ability of Students. }\end{array}$ & 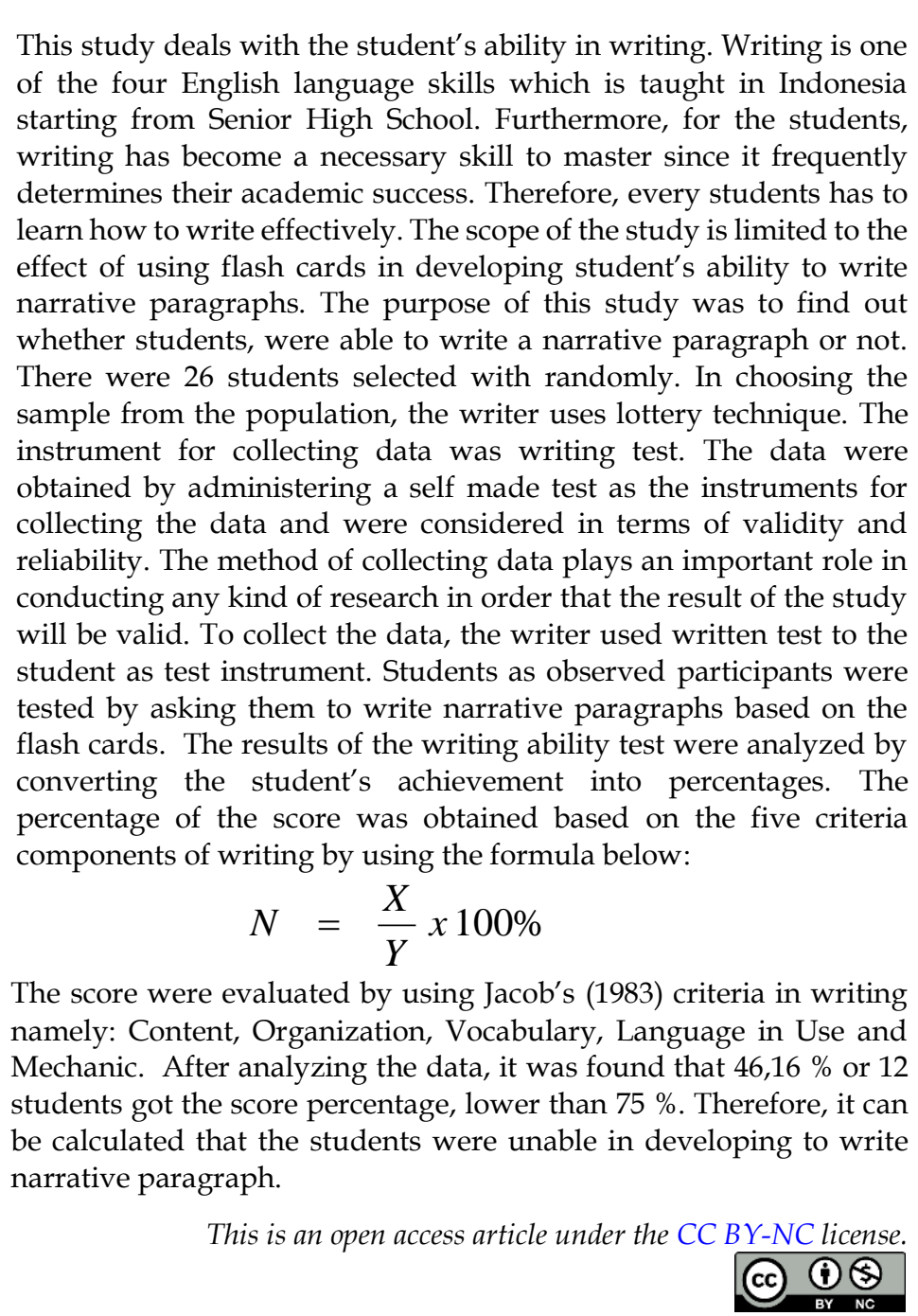 \\
\hline $\begin{array}{l}\text { Corresponding Author: } \\
\text { Jelita Lumban Gaol, } \\
\text { Pendidikan Bahasa Inggris, } \\
\text { STKIP Pelita Bangsa, } \\
\text { Jl. Kebun Lada No } 24 \text { Desa Kebun } \\
\text { Email: jelita@pelitabangsa.ac.id }\end{array}$ & , Binjai, Sumatera Utara, Indonesia, \\
\hline
\end{tabular}




\section{INTRODUCTION}

English is regarded as a foreign language in many countries and also in Indonesia. This language is used as a tool of communication from a country to another and may keep their relationship in all aspects of life. By using language as a means of communication either in spoken or written form, it allows people to talk to one another and write their thoughts and ideas. Therefore, if language doesn't exist, no one is able to express his or her thoughts and ideas to another.

Using language as a tool of communication involves the use of four language skills, there are: (1). Listening, (2). Speaking, (3). Reading and, (4). Writing that should be mastered by people in their ways of telling or expressing the thoughts and ideas. In this research, the writer wants to focus on writing. Without ignoring the other parts of basic English skills, writing is important to convey the idea through reading materials. As matter of a fact, speaking and listening are very closely related, and writing and reading are too.

Writing is one of the four English language skills which is taught in Indonesia starting from Senior High School. Furthermore, for the students, writing has become a necessary skill to master since it frequently determines their academic success. Therefore, every students has to learn how to write effectively.

The government, through the Department of Education and Culture has established a curriculum of English and has now been revised and called the 1994 curriculum of English GBPP, it is said that: "one element of GBPP is method". We all know that, there are many methods and technique in teaching English. One of the techniques is using teaching aids. Teaching aids is divided into two kinds. First is audiovisual aids that can both be heard and seen. Second is visual aids that help us hearing capacity and an aid that facilities our sight. In learning a language, the use of visual aids is very helpful because students can learn more quickly, effectively and efficiently. Learning is a complex process and visual aids are of great help in stimulating the learning of a foreign language.

Good visual aids material will help maintain the pace of the lesson and the student's motivation through visual aids stimulus. The more interesting and varied these are stimulus his imaginative power and it becomes the quicker and more effective. Morgan (1976) said that audio visual aids are the materials and devices used in learning situations to supplement the written or spoken word in the transmission of knowledge, attitudes and ideas.

In relation to developing student's ability in writing narrative paragraph through visual aids, (Butar-Butar, 2001) states that: "Children enjoy visual aids (flash cards) and use them as a natural way of expressing themselves while language is abstract, flash card for children tend to be concrete and are therefore more 'real' to the students".

In this case, flash cards will motivate the students to express something and will improve their language competence and performance too. Visual aids (flash cards) can help, motivate, and encourage the learners, so the teaching process will be relax and they will enjoy the competitive activities in writing narrative paragraph.

\section{RESEARCH METHODOLOGY}

\section{Research Design}

In designing this research, the writer conducted descriptive method. As (Nazir, 1988) states that: "Metode deskriptif adalah metode penelitian untuk membuat gambaran mengenai situasi atau kejadian, sehingga metode ini berkehendak mengadakan akumulasi data dasar belaka".

From the quotation above, it is clear that descriptive method is a method of research, which makes the description of situation, events or occurrence, so this method has an intention to accumulate the basic data. 


\section{Population and Sample}

Population, according to (Gay, 1987) stated that: "Population is the group of the people or this interesting to the researcher the group to which she or he would like the result of the study to be generalize is able".

The population of this study was all of the students of SMK-5 Swasta Kesehatan Tri Sakti Lubuk Pakam. The total number of the students was 52 students.

Statistically this population was too large for the composition analysis. Therefore, a $15 \%$ of the population were chosen as the sample. The reason for taking the number was based on Arikunto's idea (1993) say that is : "If the population consists of large number, the sample can be taken as much as $10 \%-15 \%$ or $20 \%-25 \%$ or more".

To obtain the sample, the writer used random sampling technique. (Gay, 1987) states that: "Random sampling was drawn randomly from one class of students. There was 26 students choosing the sample from the population, the writer uses lottery technique. The writer wrote each name of the population in a piece of paper, then all the paper were rolled and put in a glass. The glass was shaken and the writer took one of the papers, kept it and shook again to take another piece of paper. It was done until the writer got the 26 names of the students. Technique for Collecting Data

The data were obtained by administering a self made test as the instruments for collecting the data and were considered in terms of validity and reliability.

The method of collecting data plays an important role in conducting any kind of research in order that the result of the study will be valid. To collect the data, the writer used written test to the student as test instrument. Students as observed participants were tested by asking them to write narrative paragraphs based on the flash cards.

The writing test was conducted during the teaching learning process in the class in which the writer took it as sample. The writing test was conducted in the following stages: The work sheets were given to the students., They were asked to write their names and classes on their worksheets., The writer wrote the instructions on the blackboard and explained how to do the test., The time was given 60 minutes., During the test, the English teacher of the school assisted to the writer.

For the evaluation of the test, the writer gave the cumulative scores ranging from 0-100. To do the evaluation, there are some indicators to consider as (Jacob, 1983) said that: "There were five indicators to consider in scoring a writing test.

\section{Content}

The scoring of the content depends on the student's capability to write their ideas and information in the form of logical sentences. The criteria of scoring these were as follows:
$27-30$
Excellent to very good
For students with some knowledge of the subject matter, adequate of range development, mostly relevant to topic sentences, but lack the details.
$22-26$
Good to average
Somewhat choppy, loosely organized but the main ideas stand out.
$17-21$
Fair to poor
For the students with limited knowledge of subject, little substance inadequate development of subject.
$13-16$ Very poor
For the students who do not show knowledge of subject, non substantive, not pertinent, or not enough to evaluate.

\section{Organization}

The organization refers to the student's capability to write their ideas and information in such a good logical order to topic, and supporting sentence were clearly stated. The criteria of giving the score as the following:

$18-20 \quad$ Excellent to very good 
Provide fluent expression, ideas clearly stated, sentences were organized, logical sequence cohesive.

\section{4- 17 Good to average}

Somewhat choppy, loosely organized but the main ideas stand out.

\section{0 - 13 Fair to poor}

Non fluent ideas confused or disconnected, lack logical sequencing and

07 - 09 Very poor

Does not communicate, no organization, or not enough to evaluate.

Vocabulary

The criteria of scoring the vocabulary were given below:

18-20 Excellent to very good

Students with sophisticated range effectively word form, imitative

14- 17 Good to average

Adequate range occasionally errors, meaning not obscured.

$10-13$ Fair to poor

Limited range, frequent errors of words idiom form, choice, usage, but meaning confused or obscured.

$07-09 \quad$ Very poor

Lack of essential translation, little knowledge of English vocabulary, idioms, words, forms, or not enough to evaluate.

\section{Language Use}

Language use refers to competence in writing down the sentence either simple, complex or compound sentence correctly or logically. It also refers to the ability if using the arrangement in the sentence and some other words such as: nouns, adjective, and time signals. The criteria for scoring the language use were given below:

\section{2 - 25 Excellent to very good}

Effective complex construction, few errors of agreement, tenses, numbers, word order, articles, pronouns, prepositions.

\section{8 - 21 Good to average}

Some ineffective complex construction, frequent errors on the use of sentences elements.

11 - 17 Fair to poor

Major problem in simple complex construction, tense, word

$05-10 \quad$ Very poor

Usually no mastery of sentence construction rules dominated by errors, does not communicate, not enough to evaluate.

\section{Mechanic}

The score for the mechanics depends on the student's competence to write spelling, punctuation, capitalization, paragraphing, and hand writing whether or not can be read. The criteria of scoring the mechanic were given below:

\section{$5 \quad$ Excellent to very good}

Demonstrated mastery of punctuation, few errors in capitalization, hand writing.

$4 \quad$ Good to average 


\section{$3 \quad$ Fair to poor}

Occasional errors of punctuation, capitalization, writing sentences, but meaning not obscured.

Frequent errors of punctuation, capitalization, writing sentences, poor hand writing, meaning confused or obscured.

\section{Very poor}

No mastery of convention, dominated by errors of spelling, punctuation, capitalization, writing sentences, handwriting not enough to evaluate.

Based on those indicators, then the student's ability in writing narrative paragraph was classified in quantitative and qualitative system. The scales were as follows:

$\begin{array}{lc}\quad \text { Qualitative form } & \text { Quantitative form } \\ \text { Excellent to very good } & 90-100 \\ \text { Good to average } & 70-89 \\ \text { Fair to poor } & 30-69 \\ \text { Very poor } & 0-29\end{array}$

As stated in the previous chapter, the study was intended to find out the student's ability to develop writing narrative paragraph. So the standard ability for an individual mastery of learning delivered in the 1994 Curriculum and the Instructional System Development Procedure was used. It was stated that the standard ability for individual was more than $75 \%$ correct on the test given.

Furthermore, it was clearly stated that if : If a student was able to write narrative paragraph $50 \%$ or more of the sample get $75 \%$ or more correct on the test, the students can be categorized as able., If a student was able to write narrative paragraph less than $50 \%$ of the sample get $75 \%$ correct, they can be categorized as unable.

\section{Instrument Validation}

Instrument of validation consists of validity and reliability. Validity and reliability are general considerations in conducting a test or evaluation. The fore most of these is whether the test measures, and whether the test measure consistently and accurately.

\section{Reliability of the Test}

Reliability is the extent to which research can be repeated and show the same or similar result, ability or consistency of test result (Wallace, 1998).

Vockell (1983) also said that : "The reliability is the degree of consistency with which a test produce similar result on occasions when it theoretically should produces the same result". In other words, the reliability of a test is the consistency of the scores for an individual who is talking the test several times.

\section{Validity of the Test}

Validity in research, refers to whether or not the result of some measurement of experience really show what they claim to show (Vockell, 1983). In other words, the validity of a test refers to the concept of whether the test measures what it is designed to measure. For this study, the test is to determinate the extent to which students have ability to develop narrative paragraphs. There were several types of validity, content, construct, concurrent and predictive ability. This study applies content validity.

\section{Technique for Analyzing Data}

In this study, the writer divided the data which were analyzed in two steps. First, the writer tabulated the raw score of the students in which he tabulated the scores twice. He took the average of those scores to be the real score and then continued to count and calculated the percentage of the score. 
Second, the writer tabulated the number of correct and incorrect in writing narrative paragraph according to content, organization, vocabulary, language use, and mechanic. And after that the writer continued to count the percentage of each writing of usage that categorizes. To tabulate the result of the student's score, the mean and the percentage of each, the writer used this formula:

$$
\begin{aligned}
& \mathrm{E}=\left(\mathrm{R}_{1}\right)=\frac{m}{N}\left[\frac{N(N+1)}{2}\right] \\
& \mathrm{E}=\left(\mathrm{R}_{2}\right)=\frac{n}{N}\left[\frac{N(N+1)}{2}\right]
\end{aligned}
$$

Where :

$$
\begin{aligned}
& \mathrm{m}=\text { the number of } \mathrm{X}_{1} \text { data. } \\
& \mathrm{n}=\text { the number of } \mathrm{Y}_{1} \text { data } \\
& \mathrm{N}=\mathrm{m}+\mathrm{n} \\
& \mathrm{E}=\left(\mathrm{R}_{1}\right)=\text { mathematic purpose from the sample. } \\
& \mathrm{E}=\left(\mathrm{R}_{2}\right)=\text { mathematic purpose from the sample. } \\
& \qquad N=\frac{X}{Y} \times 100 \%
\end{aligned}
$$

Where :

$$
\begin{aligned}
& N=\text { The ability percentage } \\
& X=\text { The number of the score } \\
& Y=\text { The total number of the score }
\end{aligned}
$$

After the percentage of each score has been counted, the percentage of each score with the standard ability that has been set was compared to determine whether or not the students were able to do the test.

\section{RESULTS AND DISCUSSION}

\section{The Data}

The data for this research were obtained by administering a self made test of a writing test of writing narrative paragraph. So, the data of the study was a set of scores of student's ability to develop narrative paragraph by using flash card.

Since this study used the test that involved subjectivity, the score was scored by two raters. This is aimed at finding out the reliability of the test as suggested by Azwar. In scoring the students ability in writing, the writer made the score rating from 0-100. it was taken from five criteria components of writing based on Jacob (1983), as the indicator to measure the test.

To find the real score of the students, the score obtained by the two raters, were summed and the total was divided by two. Furthermore, the data were presented in the following descriptions: The total number of the students was 26., The total score by the first rater was 1727. (see Appendix 1)., The total score by the second rater was 2001 (see Apendix 1)., The percentage of the score was obtained based on the five criteria components of writing by using the formula below:

$$
N=\frac{X}{Y} \times 100 \%
$$

Where :

$$
\begin{aligned}
& N=\text { The ability percentage } \\
& X=\text { The number of the score } \\
& Y=\text { The total number of the score } \\
& \text { (see appendix } 4 \text { and } 5 \text { ). }
\end{aligned}
$$




\section{Data Analysis}

The reliability of the test was calculated by using the inter-rater reliability. In order to find the coefficient reliability, firstly, the interaction variance between raters II $\left(\mathrm{S}_{\mathrm{s}}{ }^{2}\right)$ (see appendix 6). The calculation showed the reliability of the test was 0.99 , this meant that this test could be regarded as reliable.

In scoring the student's ability I writing, the writer made the score rating from 0-100. It was taken from the five criteria components of writing based on Jacob, et. all as the indicator to measure the test. First of all, the writer counted student's score for each components of writing. The writer measured the student's score for each component through the consideration of each sub component within the component. For instance, to measure the student's ability in content, the writer considered about its knowledge, substantive, through development of topic sentence and relevance to assigned topic. He calculated the score twice. Rater I and rater II, then he took the average score of those two score of writing (see Appendix 2 and Appendix 3).

Table 4 (see Appendix 2) shows the student's ability for each component in which the students total score in content is 550, in organization 405 , in vocabulary is 340 , in language use 340 , and in mechanics is 107. The sum of all score of writing component 2378. Table 5 (see Appendix 3) shows the student's ability for each component in which the students total score in content is 640 , in organization is 425 , in vocabulary is 420 , in language use is 395 , and in mechanics is 121 . the sum of all score of writing component 2001.

After the writer calculated the score of the students, then he continued his study by calculating the score percentage of each component in writing skill as its indicators. In this case, the writer also calculated the \% score twice based on the score whether it is based in the score I and score II (see Appendix 4 and Appendix 5). The analysis of the scores percentage were produced by applying :

$$
N=\frac{X}{Y} \times 100 \%
$$

Where :

$$
\begin{aligned}
& N=\text { The ability percentage } \\
& X=\text { The number of the score } \\
& Y=\text { The total number of the score }
\end{aligned}
$$

Where :

$$
\begin{array}{ll}
\text { Contents } & =30 \\
\text { Organization } & =20 \\
\text { Vocabulary } & =20 \\
\text { Language use } & =25 \\
\text { Mechanics } & =5
\end{array}
$$

After the writer calculated the first and the second score and \% score for each indicator then he continued to make the conclusion of those two score and \% score and he called them as the real score and the real \% score since those number was derived from the average of the total score $1-2$ and $\%$ score of $1-2$. to make it clearer, the table of the first and second and the real score can be seen as the following:

Table 1.

The Score of the Students

\begin{tabular}{ccccc}
\hline \multirow{2}{*}{ No. } & Student's & \multicolumn{2}{c}{ Score } & Real \\
\cline { 3 - 4 } Reg. number & R1 & R2 & Score \\
\hline 1 & 001 & 80 & 80 & 80 \\
2 & 002 & 75 & 80 & 77,5 \\
3 & 003 & 62 & 75 & 68,5 \\
4 & 004 & 63 & 75 & 69 \\
5 & 005 & 59 & 80 & 69,5 \\
6 & 006 & 60 & 85 & 72,5 \\
\hline
\end{tabular}




\begin{tabular}{ccccc}
\hline \multirow{2}{*}{ No. } & Student's & \multicolumn{2}{c}{ Score } & Real \\
\cline { 3 - 4 } Reg. number & R1 & R2 & Score \\
\hline 7 & 007 & 60 & 80 & 70 \\
8 & 008 & 65 & 70 & 67,5 \\
9 & 009 & 60 & 75 & 67,5 \\
10 & 010 & 65 & 78 & 71,5 \\
11 & 011 & 64 & 74 & 69 \\
12 & 012 & 68 & 85 & 76,5 \\
13 & 013 & 65 & 85 & 75 \\
14 & 014 & 68 & 78 & 73 \\
15 & 015 & 64 & 79 & 71,5 \\
16 & 016 & 73 & 75 & 74 \\
17 & 017 & 69 & 79 & 74 \\
18 & 018 & 64 & 75 & 69,5 \\
19 & 019 & 68 & 80 & 74 \\
20 & 020 & 69 & 80 & 74,5 \\
21 & 021 & 69 & 69 & 69 \\
22 & 022 & 75 & 70 & 72,5 \\
23 & 023 & 65 & 69 & 67 \\
24 & 024 & 64 & 80 & 72 \\
25 & 025 & 69 & 75 & 72 \\
26 & 026 & 64 & 70 & 67 \\
\hline
\end{tabular}

Table 1 shows that there are 26 students who got the good to average real score. The real score is concluded after deriving from the average of the total score Rater 1 and Rater 2.

The \% score I and score II and the real \% score can be seen in the following table:

Table 2.

The Percentage of the Score

\begin{tabular}{ccccc}
\hline & \multirow{2}{*}{$\begin{array}{c}\text { Student's } \\
\text { Reg. number }\end{array}$} & $\mathbf{R} 1$ & \% & $\begin{array}{c}\text { \% of the } \\
\text { Real } \\
\text { Score }\end{array}$ \\
\cline { 3 - 4 } & & 82,00 & 82,00 & 82,00 \\
1 & 001 & 78,67 & 82,00 & 80,33 \\
2 & 002 & 58,33 & 78,67 & 68,50 \\
3 & 003 & 62,33 & 78,67 & 70,50 \\
4 & 004 & 60,67 & 83,67 & 72,17 \\
5 & 005 & 66,33 & 88,67 & 77,50 \\
6 & 006 & 71,33 & 83,67 & 77,50 \\
7 & 007 & 68,00 & 75,33 & 71,67 \\
8 & 008 & 70,33 & 78,67 & 74,50 \\
9 & 009 & 68,00 & 75,67 & 71,83 \\
10 & 010 & 65,67 & 75,33 & 70,50 \\
11 & 011 & 71,33 & 87,00 & 79,17 \\
12 & 012 & 69,00 & 87,00 & 78,00 \\
13 & 013 & 69,00 & 74,00 & 71,50 \\
14 & 014 & 72,33 & 79,67 & 76,00 \\
15 & 015 & 70,67 & 80,33 & 75,50 \\
16 & 016 & 66,33 & 79,67 & 73,00 \\
17 & 017 & 67,33 & 80,33 & 73,83 \\
18 & 018 & 70,67 & 82,00 & 76,33 \\
19 & 019 & 70,67 & 82,00 & 76,33 \\
20 & 020 & 78,00 & 71,33 & 74,67 \\
21 & 021 & & & \\
\hline
\end{tabular}




\begin{tabular}{ccccc}
\hline \multirow{2}{*}{ No. } & $\begin{array}{c}\text { Student's } \\
\text { Reg. number }\end{array}$ & $\mathbf{R}$ & \% Score & $\begin{array}{c}\text { \% of the } \\
\text { Real } \\
\text { Score }\end{array}$ \\
\cline { 3 - 4 } & 022 & 70,33 & 75,33 & 72,83 \\
22 & 023 & 66,33 & 71,33 & 68,83 \\
24 & 024 & 73,00 & 85,33 & 79,17 \\
25 & 025 & 66,33 & 78,67 & 72,50 \\
26 & 026 & 78,67 & 75,33 & 77,00 \\
\hline
\end{tabular}

\section{The Findings}

After the writer calculated the scores and the scores percentage of the test, he found that there were 12 students who were able in developing write narrative paragraph.

Since this research, the writer measured the student's ability based on the student's score percentage since the standard ability based on the curriculum and PPSI, that if $75 \%$ of the students of the evaluation score percentage, so the students are said unable to write narrative paragraphs.

Since there were 12 students $(46,15 \%)$ got upper $75 \%$ to write narrative paragraph. Therefore, it can be calculated that the students of SMK-5 Swasta Kesehatan Tri Sakti Lubuk Pakam were unable in developing to write narrative paragraph.

\section{CONCLUSION}

After analyzing the data, conclusion are drawn as follows: The percentage of score writing narrative paragraph by using flash card is $46,15 \%$, it means that the students of are unable to write narrative paragraph., Flash card cann't help the students of SMK-5 Swasta Kesehatan Tri Sakti Lubuk Pakam in developing a narrative paragraph.

\section{References}

Burns Paul, Roe Betty and Ross Lenore. 1994. Teaching Reading Today Elementary School. Boston : Houghton Miffin Company.

Collin, Mary Lou. 1983. A Short Prose Reader. New Jersey : Houghton Miffin Company.

D’Angelo Frank. 1980. Process Thought in Comparison. Massachusetts : Winthrop Publisher, Inc. Cambridge.

Gay, L. 1987. Educational Research: Competencies for Analysis an Application. Ohio : Merrill.

Jacob. 1983. English Composition Program: Teaching ESL Composition Techniques. New York : New Burry House Publisher.

Keraf, Gorys. 1980. Komposisi. Jakarta : Nusa Indah : Cetakan Ende Flores.

Lorch, Sue. 1984. A Practical Approach of Basic Writing. London : Jakarta.

Lubis, Y. 1988. Developing Communicative Providence in the English as a Foreign Language. Jakarta : Departemen Pendidikan dan Kebudayaan.

Muhyidin, Tatang. S. 1988. Writing Paragraph and Essays through Model and Exercise. Jakarta : Proyek Pengembangan Lembaga Pendidikan Tenaga Kependidikan.

Oshima, A and Hogue, A. 1981. Writing Academic English. New York: Adison Wesley.

Saraka, Drs. 1988. From Paragraph to Essay : Concepts and Practice. Jakarta : Departemen Pendidikan dan Kebudayaan.

Schoephoerster, H. 1978. Language for Meaning. Boston (New Jersey) : Houghton Miffin Company.

Sudjana. 1992. Metode Statistika. Bandung: Tarsito.

Tinambunan, W. 1988. Evaluation of Student's Achievement. Jakarta : Departemen Pendidikan dan Kebudayaan. Vockell, E. L. 1983. Education Research. New York : Mac Milan Publishing.

Wallace, M. J. 1983. Action Research for Language Teachers. Cambridge : Cambridge University Press.

Webster's. 1971. Third New International Dictionary. Spring Field : G \& G Meririan Company.

Wiston, E. G. and Burks, J. M. 1980. Let's Write English. New York: American Book.

Wright, A. 1976. Visual Materials for the Language Teacher. England : Longman. 